\title{
Ebola viral disease prevention: Perception of secondary school students in two districts in Anambra State, Nigeria
}

\author{
Nwabueze SA ${ }^{1}$, Amah CC ${ }^{2}$, \\ ${ }^{*}$ Azuike EC1,6, Anene J03, \\ Kadiri-Eneh NP4, Anameje \\ $\mathrm{OA}^{5}$ and Akudu AC1. \\ 1Department of Community \\ Medicine, Nnamdi Azikiwe \\ University Teaching Hospital, Nnewi, \\ Nigeria \\ ${ }^{2}$ Department of Paediatric Surgery, \\ University of Nigeria Teaching \\ Hospital, Ituku/Ozalla, Enugu, \\ Nigeria \\ 3Department of Health, Anambra \\ State Local Government Service \\ Commission, Awka, Anambra State, \\ Nigeria \\ ${ }^{4}$ Department of Community \\ Medicine, University of Portharcourt \\ Teaching Hospital, Portharcourt, \\ Rivers State, Nigeria \\ 5Deparment of Family Medicine, \\ Nnamdi Azikiwe University Teaching \\ Hospital, Nnewi, Nigeria \\ ${ }^{6}$ Foundation for Health and \\ Development in Nigeria \\ *Corresponding Author \\ Email:emmanazuike@yahoo.com \\ Tel.: +2348036719904
}

Ebola Viral disease (EVD) is caused by Ebola Virus. It is one of the Viral Haemorrhagic Fevers. It has a high fatality rate. Ebola virus belongs to the group of enveloped viruses that generally have high infection rate. This is because the lipid envelop helps them to enter easily into the host's cells. EVD can be prevented by good hygiene. This is because the lipid envelop covering of the virus can easily be destroyed by some chemical and physical agents.This study was carried out to assess the knowledge, attitude and practice regarding Ebola viral disease prevention measures among secondary school students in Nnewi North and Nnewi South Local Government Areas in Anambra State. This study was done durig the last ebola outbreak in Nigeria. This was a cross sectional descriptive study carried out in 2 local government areas (Nnewi North and Nnewi South) in Anambra State, Nigeria. Multi stage sampling techniques was used. Four hundred questionnaires (200 per LGA) were included in the final analysis. A structured, pretested, self administered questionnaire was used in this study. Data was analysed using SPSS version 20.0ut of the 200 respondents in Nnewi North, $73(36.5 \%)$ were males and $127(63.5 \%)$ were females. In Nnewi South, $104(52.0 \%)$ were males while $96(48.0 \%)$ were females. In Nnewi North, 190 (55.0\%) have heard of EVD, but in Nnewi South 192 (96.0\%) have heard of EVD. In Nnewi North $89.5 \%$ believed that drinking salt water would cure EVD, but in Nnewi South it was $\mathbf{7 8 \%}$. In Nnewi North $95.5 \%$ practice hand washing, while $96 \%$ practice same in Nnewi South.This study has demonstrated that almost all the students have heard of EVD. They equally had good knowledge of the preventive measures and practice them. However some misconceptions need to be corrected.

Key words: Knowledge, attitude, practice, ebola

\section{INTRODUCTION}

Ebola virus is a $19 \mathrm{~kb}$ long, non-segmented, single stranded RNA virus, which is a member of the viral family filoviridae and the causative agent of the Ebola viral disease (Pringle et al., 2005). Ebola viral disease is an example of a viral hemorrhagic fever. Hence the alternative name Ebola hemorrhagic fever. Viral hemorrhagic fevers are a diverse group of animal and human illnesses that may be caused by five distinct families of RNA viruses; Arenaviridae, Filoviridae, Bunyaviridae, Flaviridae and Rhabdoviridae.
Other examples of viral hemorrhagic fevers are Crimean Congo hemorrhagic fever, South American hemorrhagic fever, Dengue fever, Rift valley fever, Lassa fever and Yellow fever. All types of viral hemorrhagic fevers (VHF) are characterized by fever and bleeding disorders and all can progress to high fever, shock and death in many cases (Grard et al., 2012). Before outbreaks are confirmed in areas of weak surveillance, on the local or regional levels, Ebola is often mistaken for malaria, typhoid fever, 
dysentery, influenza or various bacterial infections, which may be endemic to the region (Cohen, 2004). The Ebola virus causes an acute, serious illness, which is often fatal in humans. The average Ebola viral disease (EVD) case fatality rate is around $50 \%$. However, case fatality rates have varied from $25 \%$ to $90 \%$ in past outbreaks. Ebola viral disease (EVD) first appeared in 1976 in two simultaneous outbreaks, one in Nzara (Sudan) and the other in Yambuku (Democratic Republic of Congo). The latter occurred in a village near the Ebola River, from which the disease takes its name. Five strains of the Ebola virus have been identified; Zaire, Bundibugya, Sudan, Reston and Tai forest. The Bundibugya, Zaire and Sudan Ebola Virus have been associated with large outbreaks in Africa. The virus that caused the 2014 West African outbreak belongs to the Zaire strain (WHO, 2015 and Kuhn et al., 2010). The most recent outbreak in West Africa (first cases noticed in March 2014) is the largest and most complex Ebola outbreak since the Ebola virus was first discovered in 1976 (CDC, 2015a) and CDC, 2015b). There have been more cases and deaths in this outbreak than all others combined. It has also spread between countries starting in Guinea, then spread across land borders to Sierra Leone, Liberia and Senegal and by air to Nigeria (WHO, 2015 and CDC, 2015b). The most severely affected countries, Guinea, Sierra Leone and Liberia have very weak health systems, lacking human and infrastructural resources, Liberia and Sierra Leone having only recently emerged from long periods of conflict and instability. EVD is highly contagious owing to the fact that Ebola virus belongs to the group of enveloped viruses that generally have high infection rate. This is because the lipid envelop helps them to enter easily into the host's cells. However, the good news is that sound hygienic lifestyle with effective use of antiseptic materials can go a long way to prevent contracting the infection. The simple reason to this is that the lipid envelop covering of the virus can easily be destroyed by some chemical and physical agents (e.g. some solvents, heat, low temperature, oxidizing agents like bleach, detergents, $70 \%$ alcohol solution).

In view of the mode of transmission, some risk factors have been recognized. These include lifestyle behaviours that can predispose (expose) someone to this virus: Handling bodily secretions of an infected individual e.g. blood, urine, saliva, sweat, seminal fluid, vaginal fluids, vomitus, tears, diarrhoeal stool and breast milk; Attending to a person sick with the virus; Visiting hospitals or homes where Ebola patients are hospitalized; Having handshakes with an infected individual; Exchange of personal belongings e.g. clothes, eating utensils, tooth brushes of someone infected with the Ebola virus; Coming in contact with sweat of infected person; Overcrowding; Handling of bush meat with bare hands/eating poorly cooked bush meat, etc. The incubation period, is 2 to 21 days, most often this is between 4 to 10 days (WHO, 2015; CDC 2015c and Goeijenbier et al., 2014). Humans are not infectious until they develop symptoms.

A study done in Sierra Leone reported high levels of awareness regarding EVD, but low comprehensive knowledge on EVD. Also the preventive practices against EVD were low and there were a lot of misconceptions regarding EVD. Furthermore, there was very high level of stigma and discrimination towards EVD victims (CRS, 2015). This study was carried out to assess the knowledge, attitude and practice regarding Ebola viral disease prevention measures among secondary school students in Nnewi North and Nnewi South Local Government Areas in Anambra State. This study was done durig the last ebola outbreak in Nigeria.

\section{METHODOLOGY}

Nnewi North is a local government area (LGA) in Anambra state, South-east, Nigeria. Nnewi is the only town in Nnewi North LGA. There are four villages that make up the town: Otolo, Uruagu, Umudim and Nnewichi. Nnewi has a population of 391,227 according to the 2006 National population census (Wikipedia, 2015). Nnewi North LGA hosts 8 government owned and 48 privately owned secondary schools. Nnewi South is a Local Government Area in Anambra State, South-east Nigeria, with its headquarters at Ukpor. Other towns that make up the LGA include Ekwulumili, Amichi, Azigbo, Unubi, Ezinifite, Osumenyi, Utuh, Akwaihedi, Ogbodi and Ebenator. Its population is approximately 233,360 according to the 2006 population census (NPCN 2009). Nnewi South hosts 17 government owned and 22 privately owned secondary schools.

Study population: The study population were secondary school students in Nnewi North and South LGAs of Anambra State.

Study Design: This was a cross-sectional descriptive study. Sample Size Determination:The minimum sample size was calculated using the formula below (Araoye, 2004);

$$
\mathrm{N}=\frac{\mathrm{z}^{2} \mathrm{pq}}{\mathrm{d}^{2}}
$$

Where;

$\mathrm{N}=$ minimum sample size

$\mathrm{Z}=$ standard normal deviate at $95 \%$ confidence level (ie 1.96)

$\mathrm{P}=$ proportion of target population estimated to have characteristic of interest; taken as $50 \%(0.5)$

$\mathrm{q}=1-\mathrm{p}$ (ie $1-0.5$ )

$\mathrm{d}=$ margin of error, usually set at $5 \%$ (ie 0.05 )

$\mathrm{N}=\frac{1.96^{2} \times 0.5 \times 0.5}{0.05^{2}}=384$

$$
0.05^{2}
$$

\section{Attrition}

An anticipated $10 \%$ attrition rate was assumed. Hence $10 \%$ of the calculated minimum sample size was added:

$$
\frac{10}{100} \times \frac{384}{1}=38.4
$$

The final calculated sample size was $384+38.4=422$. So 422 questionnaires (211 per LGA) were distributed. 
However only 400 questionnaires (200 per LGA), were included in data analysis.

Sampling Technique: Multi-stage sampling technique was used:

Stage I: $\quad$ Simple random sampling technique was used to select three schools from each local government giving a total of six schools.

Stage II:Stratified sampling was used in selecting the respondents for the study.

Study Instrument: A Structured, self-administered questionnaire was distributed to the respondents after obtaining verbal consent from them. The questionnaire was divided into four sections. Section A contained sociodemographic data, section B: knowledge of the respondents, section C: attitude and section D: preventive measures practiced.

Data Analysis: Data obtained was analyzed using SPSS version 20 , percentages were worked out and finally data was represented in tables.

Ethical Consideration: Approval was obtained from the ethical review board of the Nnamdi Azikiwe University Teaching Hospital Nnewi. The consent of the School Principals was obtained as well as that of the individual respondents.

Inclusion Criteria: Eligible respondents who gave their consent.

Exclusion Criteria: Students that were not in the selected schools. Students in the selected schools but were sitting for the Senior School Certificate exam during the study. Students who did not give their consent. Students that were not randomly selected from stratified sub groups in the selected schools.

\section{RESULTS}

Table 1 shows the socio-demographic characteristics of the respondents. Out of the 200 respondents in Nnewi North, $73(36.5 \%)$ were males and $127(63.5 \%)$ were females. With regards to their family size, $45(22.5 \%)$ were 2 to 4 in the family, $103(51.5 \%)$ were 5 to 7 persons while $52(26.0 \%)$ were greater than 7 in the family. Out of the 200 respondents 197(98.5\%) were Ibos, 2(1.0\%) were Yorubas, none was Hausa, while $1(0.5 \%)$ was from other tribes in Nigeria. Most of the respondents 199(99.5\%) were Christians, none of them was Islam or Traditionalist, while $1(0.5 \%)$ practice other forms of religion. With regards to the highest educational levels of the parents of the respondents, $6(3.0 \%)$ of fathers had no formal education, $20(10.0 \%)$ had primary education, 81(40.5\%) had secondary education, 93(46.5\%) had tertiary education. Also $2(1.0 \%)$ of the mothers had no formal education, $20(10.0 \%)$ had primary, $82(41.2 \%)$ had secondary education, 96(48.0\%) had tertiary education. Thirteen $(6.5 \%)$ of the fathers were farmers, $18(9.0 \%)$ were professionals, $11(5.5 \%)$ were bankers, $109(54.5 \%)$ were traders, and $49(24.5 \%)$ of the fathers had other forms of occupation. Six $(3.0 \%)$ of the mothers were farmers, $60(30.0 \%)$ were professionals, $6(3.0 \%)$ bankers, $114(57.0 \%)$ were traders and $14(7.0 \%)$ had other types of occupation.

Out of 200 respondents studies in Nnewi South, 104 $(52.0 \%)$ were males while $96(48.0 \%)$ were females. Thirty six $(18.0 \%)$ had a family size of 2 to $4,106(53.0 \%)$ with a family size of 5 to 7 , and $58(29.0 \%)$ had a family size greater than 7. With regards to tribe/ethnicity, 195 (97.5\%) were Ibos, $2(1.0 \%)$ were Yorubas, $1(0.5 \%)$ was Hausa and $2(1.0 \%)$ were from other tribes in Nigeria. Out of 200 respondents, $194(97.0 \%)$ were Christians, 2 (1.0\%) were Islam, and $4(2.0 \%)$ practiced Traditional religion. With regards to the fathers' highest educational level, $4(2.0 \%)$ had no formal education, $39(19.5 \%)$ attended primary school, $91(45.5 \%)$ had secondary education, 66(33.0\%) had tertiary education. One $(0.5 \%)$ of the mothers had no formal education, $28(14.0 \%)$ went to primary school, 104 $(52.0 \%)$ went to secondary school, while 67(33.5\%) acquired tertiary education. With regards to the parents' occupation, majority of their fathers were traders 96 $(48.0 \%), 36(18.0 \%)$ were farmers, $29(14.5 \%)$ were professionals, $11(5.5 \%)$ were bankers, $2(1.0 \%)$ were hunters while $26(13.0 \%)$ had other types of occupation, while $23(11.5 \%)$ of the mothers were farmers, $44(22.0 \%)$ were professionals, 5 (2.5\%) were bankers, 118 (39.0\%) were traders, while 10 (5.0\%) had other forms of occupation.

Table 2 shows the knowledge of the respondents regarding EVD. Table 2 shows that $190(55.0 \%)$ of the respondents in Nnewi North and 192(96.0\%) in Nnewi South have heard of EVD, $27.0 \%$ in Nnewi North got their information from their parents, while in Nnewi South, $26.0 \%$ got the information from their parents, $45.0 \%$ (Nnewi North) and 57.0\% (Nnewi South) through the radio, 61.0\% (Nnewi North) and 47.5\% (Nnewi South) through the television, $30 \%$ in Nnewi North and 30.5\% in Nnewi South from the newspaper, $22.5 \%$ in Nnewi North and $21.0 \%$ in Nnewi South from the church, 26.5\% (Nnewi North) and $19.0 \%$ (Nnewi South) from their schools, $27.5 \%$ and $15.0 \%$ of the respondents from Nnewi North and Nnewi South respectively got their information from their friends and 13.5\% (Nnewi North) and 10.5\% (Nnewi South) from the market place. On the other hand, majority of the respondents $72.5 \%$ and $77.0 \%$ from Nnewi North and Nnewi South respectively believed EVD existed in Nigeria. With regards to how EVD can be contracted or acquired, $88.5 \%$ in Nnewi North believed it can be acquired through eating bush meat while in Nnewi South $90.0 \%$ believed it can be acquired through eating bush meat; 88.0\% (Nnewi North) and $83.0 \%$ (Nnewi South) through sexual intercourse; $84.0 \%$ (Nnewi North) and $77.0 \%$ (Nnewi South) through kissing; 93.5\% in Nnewi North and 88.5\% in Nnewi South through blood; $91.0 \%$ and $83.0 \%$ through sweat from Nnewi North and South respectively; 90.0\% (Nnewi North) and 80.5\% (Nnewi South) through 
Issues Sci. Res. 4

Table 1. Socio-demographic characteristics of the respondents

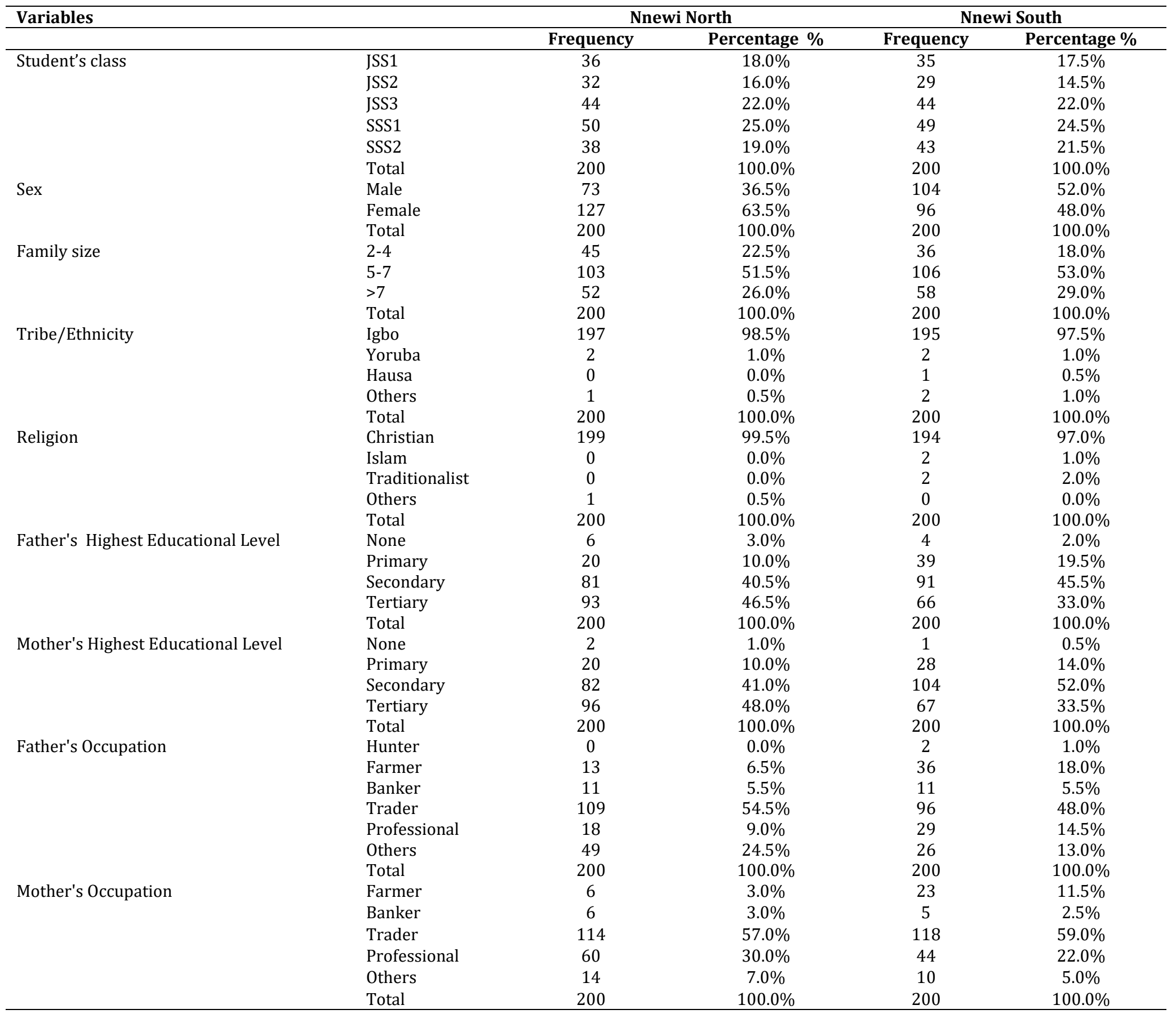

saliva; 84.5\% (Nnewi North) and 74.0\% (Nnewi South) through urine; $94.5 \%$ (Nnewi North) and $88.0 \%$ (Nnewi South) through sharing of personal belongings; $83.5 \%$ (Nnewi North) and 85.0\% (Nnewi South) through body contact while $87.0 \%$ (Nnewi North) and $85.0 \%$ (Nnewi South) through attending burial ceremonies that require touching the body of the dead suspected to have died of Ebola. Sixty one $(30.5 \%)$ of the respondents in Nnewi North and $45.0 \%$ in Nnewi South believed EVD can be transmitted through mosquito bite while $52.0 \%$ from Nnewi North and $62.5 \%$ in Nnewi South believed it can be transmitted through the air.

Regarding how EVD can be prevented, 95.0\% (Nnewi North) and $90.0 \%$ (Nnewi South) believed EVD can be prevented by avoiding consumption of bush meat, 95.0\% (Nnewi North) and 90.5\% (Nnewi South) by avoiding close body contact and contact with bodily fluids, $93.0 \%$ and $88.0 \%$ of the respondents from Nnewi North and South 
Table 2.Knowledge of Ebola viral Disease

\begin{tabular}{|c|c|c|c|c|c|c|}
\hline \multirow[t]{2}{*}{ Variables } & \multicolumn{3}{|c|}{ Nnewi North } & \multicolumn{3}{|c|}{ Nnewi South } \\
\hline & \multicolumn{2}{|c|}{ Frequency } & \multirow{2}{*}{$\begin{array}{c}\text { Percentage \% } \\
95.0 \%\end{array}$} & \multicolumn{2}{|r|}{ Frequency } & \multirow{2}{*}{$\begin{array}{c}\text { Percentage } \% \\
96.0 \%\end{array}$} \\
\hline Have you heard of EVD before & Yes & 190 & & Yes & 192 & \\
\hline & No & 10 & $5.0 \%$ & No & 8 & $4.0 \%$ \\
\hline & Total & 200 & $100.0 \%$ & Total & 200 & $100.0 \%$ \\
\hline \multicolumn{7}{|l|}{ Source of knowledge } \\
\hline \multirow[t]{3}{*}{ Parents } & Yes & 54 & $27.0 \%$ & Yes & 52 & $26.0 \%$ \\
\hline & No & 146 & $73.0 \%$ & No & 148 & $74.0 \%$ \\
\hline & Total & 200 & $100.0 \%$ & Total & 200 & $100.0 \%$ \\
\hline & Yes & 90 & $45.0 \%$ & Yes & 114 & $57.0 \%$ \\
\hline & No & 110 & $55.0 \%$ & No & 86 & $43.0 \%$ \\
\hline & Total & 200 & $100.0 \%$ & Total & 200 & $100.0 \%$ \\
\hline \multicolumn{7}{|l|}{ Television } \\
\hline & Yes & 122 & $61.0 \%$ & Yes & 95 & $47.5 \%$ \\
\hline & No & 78 & $39.0 \%$ & No & 105 & $52.5 \%$ \\
\hline & Total & 200 & $100.0 \%$ & Total & 200 & $100.0 \%$ \\
\hline \multicolumn{7}{|l|}{ Newspaper } \\
\hline & Total & 200 & $100.0 \%$ & Total & 200 & $100.0 \%$ \\
\hline \multicolumn{7}{|l|}{ Church } \\
\hline & Yes & 45 & $22.5 \%$ & Yes & 42 & $21.0 \%$ \\
\hline & No & 155 & $77.5 \%$ & No & 158 & $79.0 \%$ \\
\hline & Total & 200 & $100.0 \%$ & Total & 200 & $100.0 \%$ \\
\hline \multicolumn{7}{|l|}{ School } \\
\hline & Yes & 53 & $26.5 \%$ & Yes & 38 & $19.0 \%$ \\
\hline & No & 147 & $73.5 \%$ & No & 162 & $81.0 \%$ \\
\hline & Total & 200 & $100.0 \%$ & Total & 200 & $100.0 \%$ \\
\hline \multicolumn{7}{|l|}{ Friends } \\
\hline & Yes & 55 & $27.5 \%$ & Yes & 30 & $15.0 \%$ \\
\hline & No & 145 & $72.5 \%$ & No & 170 & $85.0 \%$ \\
\hline & Total & 200 & $100.0 \%$ & Total & 200 & $100.0 \%$ \\
\hline Market Place & & & & & & \\
\hline & Yes & 27 & $13.5 \%$ & Yes & 21 & $10.5 \%$ \\
\hline & No & 173 & $86.5 \%$ & No & 179 & $89.5 \%$ \\
\hline & Total & 200 & $100.0 \%$ & Total & 200 & $100.0 \%$ \\
\hline & Total & 200 & $100.0 \%$ & Total & 200 & $100.0 \%$ \\
\hline How can it be contracted/acquired & & & & & & \\
\hline Eating bush meat & Yes & 177 & $88.5 \%$ & Yes & 180 & $90.0 \%$ \\
\hline & No & 23 & $11.5 \%$ & No & 20 & $10.0 \%$ \\
\hline & Total & 200 & $100.0 \%$ & Total & 200 & $100.0 \%$ \\
\hline Sexual intercourse & Yes & 170 & $85.0 \%$ & Yes & 166 & $83.0 \%$ \\
\hline & No & 30 & $15.0 \%$ & No & 34 & $17.0 \%$ \\
\hline & Total & 200 & $100.0 \%$ & Total & 200 & $100.0 \%$ \\
\hline Kissing & Yes & 168 & $84.0 \%$ & Yes & 154 & $77.0 \%$ \\
\hline & No & 32 & $16.0 \%$ & No & 46 & $23.0 \%$ \\
\hline & Total & 200 & $100.0 \%$ & Total & 200 & $100.0 \%$ \\
\hline Contact with the person's blood & Yes & 187 & $93.5 \%$ & Yes & 177 & $88.5 \%$ \\
\hline & No & 13 & $6.5 \%$ & No & 23 & $11.5 \%$ \\
\hline & Total & 200 & $100.0 \%$ & Total & 200 & $100.0 \%$ \\
\hline Contact with the person's sweat & Yes & 182 & $91.0 \%$ & Yes & 166 & $83.5 \%$ \\
\hline & No & 18 & $9.0 \%$ & No & 34 & $17.0 \%$ \\
\hline & Total & 200 & $100.0 \%$ & Total & 200 & $100.0 \%$ \\
\hline Contact with the person's saliva & Yes & 180 & $90.0 \%$ & Yes & 161 & $80.5 \%$ \\
\hline & No & 20 & $10.0 \%$ & No & 39 & $19.5 \%$ \\
\hline & Total & 200 & $100.0 \%$ & Total & 200 & $100.0 \%$ \\
\hline Contact with the person's urine & Yes & 169 & $84.5 \%$ & Yes & 148 & $74.0 \%$ \\
\hline & No & 31 & $15.5 \%$ & No & 52 & $26.0 \%$ \\
\hline & Total & 200 & $100.0 \%$ & Total & 200 & $100.0 \%$ \\
\hline
\end{tabular}


Issues Sci. Res. 6

Table 2 Cont.

\begin{tabular}{|c|c|c|c|c|c|c|}
\hline \multirow[t]{3}{*}{ Sharing personal belonging } & Yes & 189 & $94.5 \%$ & Yes & 176 & $88.0 \%$ \\
\hline & No & 11 & $5.5 \%$ & No & 24 & $12.0 \%$ \\
\hline & Total & 200 & $100.0 \%$ & Total & 200 & $100.0 \%$ \\
\hline \multirow[t]{3}{*}{ Having body contact with the person } & Yes & 167 & $83.5 \%$ & Yes & 170 & $85.0 \%$ \\
\hline & No & 33 & $16.5 \%$ & No & 30 & $15.0 \%$ \\
\hline & Total & 200 & $100.0 \%$ & Total & 200 & $100.0 \%$ \\
\hline Attending burial ceremonies that requires touching the body & Yes & 174 & $87.0 \%$ & Yes & 170 & $85.0 \%$ \\
\hline \multirow[t]{2}{*}{ of the dead suspected to have died of Ebola } & No & 26 & $13.0 \%$ & No & 30 & $15.0 \%$ \\
\hline & Total & 200 & $100.0 \%$ & Total & 200 & $100.0 \%$ \\
\hline \multirow{2}{*}{ Can EVD be transmitted through mosquito bite? } & No & 139 & $69.5 \%$ & No & 110 & $55.5 \%$ \\
\hline & Total & 200 & $100.0 \%$ & Total & 200 & $100.0 \%$ \\
\hline \multirow[t]{3}{*}{ Can EVD be transmitted through the air? } & Yes & 104 & $52.0 \%$ & Yes & 139 & $69.5 \%$ \\
\hline & No & 96 & $48.0 \%$ & No & 61 & $30.5 \%$ \\
\hline & Total & 200 & $100.0 \%$ & Total & 200 & $100.0 \%$ \\
\hline \multicolumn{7}{|l|}{ How can EVD be avoided? } \\
\hline \multirow[t]{3}{*}{ Avoid consumption of bush meat } & Yes & 190 & $95.0 \%$ & Yes & 181 & $90.5 \%$ \\
\hline & No & 10 & $5.0 \%$ & No & 19 & $9.5 \%$ \\
\hline & Total & 200 & $100.0 \%$ & Total & 200 & $100.0 \%$ \\
\hline \multirow{2}{*}{ Avoid close body contact and contact with bodily fluids } & No & 10 & $5.0 \%$ & No & 20 & $10.0 \%$ \\
\hline & Total & 200 & $100.0 \%$ & Total & 200 & $100.0 \%$ \\
\hline \multirow[t]{3}{*}{ Use of hand glove } & Yes & 186 & $93.0 \%$ & Yes & 176 & $88.0 \%$ \\
\hline & No & 14 & $7.0 \%$ & No & 24 & $12.0 \%$ \\
\hline & Total & 200 & $100.0 \%$ & Total & 200 & $100.0 \%$ \\
\hline \multirow{3}{*}{ Hand washing } & Yes & 190 & $95.0 \%$ & Yes & 174 & $87.0 \%$ \\
\hline & No & 10 & $5.0 \%$ & No & 26 & $13.0 \%$ \\
\hline & Total & 200 & $100.0 \%$ & Total & 200 & $100.0 \%$ \\
\hline \multirow[t]{3}{*}{ Use hand sanitizer } & Yes & 189 & $94.5 \%$ & Yes & 174 & $87.0 \%$ \\
\hline & No & 11 & $5.5 \%$ & No & 26 & $13.0 \%$ \\
\hline & Total & 200 & $100.0 \%$ & Total & 200 & $100.0 \%$ \\
\hline \multirow[t]{3}{*}{ Avoid burials that require touching the body of the dead } & Yes & 91 & $45.5 \%$ & Yes & 120 & $60.0 \%$ \\
\hline & No & 109 & $54.5 \%$ & No & 80 & $40.0 \%$ \\
\hline & Total & 200 & $100.0 \%$ & Total & 200 & $100.0 \%$ \\
\hline \multicolumn{7}{|l|}{ What are the symptoms of Ebola } \\
\hline \multirow[t]{2}{*}{ Fever } & Yes & 87 & $43.5 \%$ & Yes & 86 & $43.0 \%$ \\
\hline & No & 113 & $56.5 \%$ & No & 114 & $57.0 \%$ \\
\hline \multirow{2}{*}{ Headache } & No & 139 & $69.5 \%$ & No & 129 & $64.5 \%$ \\
\hline & Total & 200 & $100.0 \%$ & Total & 200 & $100.0 \%$ \\
\hline Weakness & Yes & 83 & $41.5 \%$ & Yes & 75 & $37.5 \%$ \\
\hline & No & 117 & $58.5 \%$ & No & 125 & $62.5 \%$ \\
\hline & Total & 200 & $100.0 \%$ & Total & 200 & $100.0 \%$ \\
\hline Muscle pain & Yes & 43 & $21.5 \%$ & Yes & 29 & $14.5 \%$ \\
\hline & No & 157 & $78.5 \%$ & No & 171 & 85.5 \\
\hline & Total & 200 & $100.0 \%$ & Total & 200 & $100.0 \%$ \\
\hline Vomiting & Yes & 96 & $48.0 \%$ & Yes & 76 & $38.0 \%$ \\
\hline & No & 104 & $52.0 \%$ & No & 124 & $62.0 \%$ \\
\hline & Total & 200 & $100.0 \%$ & Total & 200 & $100.0 \%$ \\
\hline Diarrhoea & Yes & 46 & $23.0 \%$ & Yes & 31 & $15.5 \%$ \\
\hline & No & 154 & $77.0 \%$ & No & 169 & $84.5 \%$ \\
\hline & Total & 200 & $100.0 \%$ & Total & 200 & $100.0 \%$ \\
\hline Rash & Yes & 61 & $30.5 \%$ & Yes & 49 & $24.5 \%$ \\
\hline & No & 139 & $69.5 \%$ & No & 151 & $75.5 \%$ \\
\hline & Total & 200 & $100.0 \%$ & Total & 200 & $100.0 \%$ \\
\hline Bleeding from the nose, mouth or anus & Yes & 121 & $60.5 \%$ & Yes & 92 & $46.0 \%$ \\
\hline & No & 79 & $39.5 \%$ & No & 108 & $54.0 \%$ \\
\hline & Total & 200 & $100.0 \%$ & Total & 200 & $100.0 \%$ \\
\hline Can EVD be treated & Yes & 143 & $71.5 \%$ & Yes & 131 & $65.5 \%$ \\
\hline & No & 57 & $28.5 \%$ & No & 69 & $34.5 \%$ \\
\hline & Total & 200 & $100.0 \%$ & Total & 200 & $100.0 \%$ \\
\hline
\end{tabular}


respectively by the use of hand gloves, 95.0\% (Nnewi North) and $87.0 \%$ (Nnewi South) by hand washing, 94.5\% (Nnewi North) and $87.0 \%$ (Nnewi South) by use of hand sanitizers while $45.5 \%$ from Nnewi North and $40.0 \%$ from Nnewi South by avoiding burial ceremonies. With regards to knowledge of symptoms of EVD, majority of the respondents have good knowledge of the symptoms; fever 45.5\% (Nnewi North) and 43.0\% (Nnewi South), weakness $41.5 \%$ and $35.5 \%$ Nnewi North and South respectively, muscle pain $21.5 \%$ and $14.5 \%$ respectively, vomiting $48.0 \%$ (Nnewi North) and 38.0\% (Nnewi South), diarrhoea 23.0\% (Nnewi North) and $15.5 \%$ (Nnewi South), rashes $30.5 \%$ and $24.5 \%$ respectively, and bleeding from the nose, mouth or anus $60.5 \%$ and $46.0 \%$ from Nnewi North and South respectively. Concerning treatment, $71.5 \%$ and $65.5 \%$ of the respondents from Nnewi North and South respectively believed EVD can be treated.

Table 3 shows the attitude of the respondents towards prevention of EVD. Out of 200 respondents in Nnewi North, $9.5 \%$ would keep it secret if he or she had any of the symptoms of EVD, while out of the 200 respondents in Nnewi South, $18.5 \%$ would keep it secret. In Nnewi North $37.0 \%$ of the respondents would seat close to a person who recovered from EVD, while only $32.0 \%$ would do same in Nnewi South.

Table 4 shows practices of the respondents towards prevention of EVD. In Nnewi North, $95.5 \%$ of the respondents and in Nnewi South $96.0 \%$ practice hand washing with soap and water. Ninety one percent of the respondents in Nnewi North agreed the school provided facilities for hand washing while in Nnewi South, 93.0\% admitted the school provided them with facilities for hand washing.

\section{DISCUSSION}

On the knowledge of Ebola viral disease, the study shows that nearly all the respondents; 190 (95.0\%) in Nnewi North and 192 (96.0\%) in Nnewi South have heard of Ebola viral disease. Also, majority of the respondents, 145 (72.5\%) from Nnewi North and 154 (77.0\%) from Nnewi South believed Ebola existed in Nigeria. This is similar to the findings of studies done in Sierra Leone(Chan, 2014 and WHO, 2015) which reported that nearly every Sierra Leonean has heard about Ebola. With regards to the knowledge of preventive measures against the disease, 190 (95.0\%) respondents from Nnewi North and 180 (90.5\%) respondents from Nnewi South agreed EVD can be prevented by avoiding close body contacts and contact with bodily fluids. Such level of knowledge of prevention of EVD by avoiding contact with cases was also reported in Sierra Leone. However, in contrast to the situation in Sierra Leone where $85 \%$ of the respondents agreed with the statement that one can protect oneself by avoiding funeral or burial rituals that require handling the body of someone who died of Ebola, only 45.5\% (Nnewi North) and 40\% (Nnewi
South) agreed with the statement in this study. On the misconception about transmission of Ebola viral disease, some respondents $30.5 \%$ in Nnewi North and $40.0 \%$ in Nnewi South) agreed EVD can be transmitted through mosquito bite. This shows that among the respondents some are yet to get the appropriate knowledge about EVD transmission.

On the attitude towards prevention of EVD, only very few of the respondents $9.5 \%$ (Nnewi North) and 18.5\% (Nnewi South) would keep it secret if he or she had any of the symptoms of EVD, while $59.5 \%$ of respondents in Nnewi North and $63.5 \%$ in Nnewi South would not allow someone who had recovered from the disease into their homes. Also in Nnewi North and Nnewi South respectively, 37.0\% and $32.0 \%$ of the respondents would seat close to a person who recovered from the disease. Furthermore, none of the respondents in Nnewi North would treat an EVD case at home, while $1.5 \%$ of the respondents in Nnewi South would treat an EVD case at home. In Guinea 33\% of the respondents claimed they would treat the symptoms at home for at least 3-4 weeks ${ }^{6}$. Among the 200 respondents in Nnewi North $8.5 \%$ believed that bathing with salt water could prevent EVD but in Nnewi South 20.5\% believed bathing with salt water could prevent or cure Ebola disease. A higher percentage (42\%) was reported in Sierra leone (Chan, 2014). Bathing with salt water and drinking of salt water was wrongly propagated in Nigeria during the ebola outbreak. There were even cases of death from drinking salt water in Nigeria during the ebola outbreak. A great number of the respondents $95.5 \%$ and $96.0 \%$ from Nnewi North and Nnewi South respectively practice handwashing with soap and water. This is higher than the rate in Sierra Leone where $70 \%$ of respondents practice handwashing with soap and water in order to help prevent EV (Chan, 2014) These high levels of practice of handwashing could be explained by the massive promotion of hand washing by the government and agencies during the outbreak of EVD in the country, which was also the period this study was conducted.

In conclusion, this study has demonstrated that almost all the students have heard of Ebola viral disease and knew it existed in Nigeria. A good number of them knew various modes of transmission and spread of the disease. They equally had good knowledge of the preventive measures and practice them. However a good number of them still believe dead bodies could not be a source of the infection; that EVD can be transmitted through mosquito bites and that bathing with salt water would prevent Ebola.

Based on these findings we recommend continued awareness campaigns on EVD and its preventive measures. We also recommend continuous periodic training of teachers on EVD so that they will transfer the knowledge to the students.

\section{Conflict of Interests}

The authors declare that there is no conflict of interests regarding the publication of the paper. 
Issues Sci. Res. $\quad 8$

Table 3. Attitude of respondents towards prevention of EVD

\begin{tabular}{|c|c|c|c|c|c|c|}
\hline \multirow[t]{2}{*}{ Variables } & \multicolumn{3}{|c|}{ Nnewi North } & \multicolumn{3}{|c|}{ Nnewi South } \\
\hline & & Frequency & Percentage \% & & Frequency & Percentage \% \\
\hline \multirow{3}{*}{$\begin{array}{l}\text { If you had any of the symptom above, would you keep it } \\
\text { secret? }\end{array}$} & Yes & 19 & $9.5 \%$ & Yes & 37 & $18.5 \%$ \\
\hline & No & 181 & $90.5 \%$ & No & 163 & $81.5 \%$ \\
\hline & Total & 200 & $100.0 \%$ & Total & 200 & $100.0 \%$ \\
\hline \multirow{3}{*}{$\begin{array}{l}\text { Would you allow someone who had recovered from the } \\
\text { disease to sit beside you on the seat in the class? }\end{array}$} & Yes & 74 & $37.0 \%$ & Yes & 64 & $32.0 \%$ \\
\hline & No & 126 & $63.0 \%$ & No & 136 & $68.0 \%$ \\
\hline & Total & 200 & $100.0 \%$ & Total & 200 & $100.0 \%$ \\
\hline \multirow{2}{*}{$\begin{array}{l}\text { Would you allow someone who had recovered from the } \\
\text { disease into your house? }\end{array}$} & Yes & 81 & $40.5 \%$ & Yes & 73 & $36.5 \%$ \\
\hline & Total & 200 & $100.0 \%$ & Total & 200 & $100.0 \%$ \\
\hline \multicolumn{7}{|l|}{$\begin{array}{l}\text { If somebody you know had the disease, where would you } \\
\text { direct the person for treatment? }\end{array}$} \\
\hline \multirow[t]{3}{*}{ Prayer house } & Yes & 29 & $14.5 \%$ & Yes & 20 & $10.0 \%$ \\
\hline & No & 171 & $85.5 \%$ & No & 180 & $90.0 \%$ \\
\hline & Total & 200 & $100.0 \%$ & Total & 200 & $100.0 \%$ \\
\hline \multirow{2}{*}{ Treat the person at home } & Yes & 0 & $0.0 \%$ & Yes & 3 & $1.5 \%$ \\
\hline & No & 200 & $100.0 \%$ & No & 197 & $98.5 \%$ \\
\hline \multirow{2}{*}{ Chemist } & No & 200 & $100.0 \%$ & No & 197 & $98.5 \%$ \\
\hline & Total & 200 & $100.0 \%$ & Total & 200 & $100.0 \%$ \\
\hline \multirow[t]{3}{*}{ Traditional doctor } & Yes & 5 & $2.5 \%$ & Yes & 5 & $2.5 \%$ \\
\hline & No & 195 & $97.5 \%$ & No & 195 & $97.5 \%$ \\
\hline & Total & 200 & $100.0 \%$ & Total & 200 & $100.0 \%$ \\
\hline \multirow[t]{3}{*}{ Hospital } & Yes & 167 & $83.5 \%$ & Yes & 166 & $83.0 \%$ \\
\hline & No & 33 & $16.5 \%$ & No & 34 & $17.0 \%$ \\
\hline & Total & 200 & $100.0 \%$ & Total & 200 & $100.0 \%$ \\
\hline \multicolumn{7}{|l|}{ Do you believe drinking salt water could prevent or cure } \\
\hline \multirow[t]{3}{*}{ EVD disease? } & Yes & 21 & $10.5 \%$ & Yes & 44 & $22.0 \%$ \\
\hline & No & 179 & $89.5 \%$ & No & 156 & $78.0 \%$ \\
\hline & Total & 200 & $100.0 \%$ & Total & 200 & $100.0 \%$ \\
\hline \multirow{3}{*}{$\begin{array}{l}\text { Do you believe bathing salt water could prevent or cure } \\
\text { Ebola disease? }\end{array}$} & Yes & 17 & $8.5 \%$ & Yes & 41 & $20.5 \%$ \\
\hline & No & 183 & $91.5 \%$ & No & 159 & $79.5 \%$ \\
\hline & Total & 200 & $100.0 \%$ & Total & 200 & $100.0 \%$ \\
\hline \multirow[t]{2}{*}{ Do you usually set traps in the bush to catch bush meat? } & Yes & 49 & $24.5 \%$ & Yes & 64 & $32.0 \%$ \\
\hline & No & 151 & $75.5 \%$ & No & 136 & $68.0 \%$ \\
\hline \multirow{2}{*}{$\begin{array}{l}\text { If yes, do you still set traps atter you neard the news about } \\
\text { Ebola? }\end{array}$} & No & 174 & $87.0 \%$ & No & 169 & $84.5 \%$ \\
\hline & Total & 200 & $100.0 \%$ & Total & 200 & $100.0 \%$ \\
\hline \multirow[t]{3}{*}{ Do you like eating bush meat? } & Yes & 100 & $50.0 \%$ & Yes & 106 & $53.0 \%$ \\
\hline & No & 100 & $50.0 \%$ & No & 94 & $47.0 \%$ \\
\hline & Total & 200 & $100.0 \%$ & Total & 200 & $100.0 \%$ \\
\hline \multirow{3}{*}{$\begin{array}{l}\text { If yes, do you still eat bush meat after you heard the news } \\
\text { about Ebola? }\end{array}$} & Yes & 30 & $15.0 \%$ & Yes & 31 & $15.5 \%$ \\
\hline & No & 170 & $85.0 \%$ & No & 169 & $84.5 \%$ \\
\hline & Total & 200 & $100.0 \%$ & Total & 200 & $100.0 \%$ \\
\hline \multirow{3}{*}{$\begin{array}{l}\text { Do you still shake hands with your friends after you heard } \\
\text { the Ebola news? }\end{array}$} & Yes & 76 & $38.0 \%$ & Yes & 36 & $18.0 \%$ \\
\hline & No & 124 & $62.0 \%$ & No & 164 & $82.0 \%$ \\
\hline & Total & 200 & $100.0 \%$ & Total & 200 & $100.0 \%$ \\
\hline
\end{tabular}

Table 4. Practices towards prevention of EVD

\begin{tabular}{|c|c|c|c|c|c|c|}
\hline \multirow[t]{2}{*}{ Practices towards prevention of EVD } & & \multicolumn{2}{|c|}{ Nnewi North } & \multicolumn{3}{|c|}{ Nnewi South } \\
\hline & & Frequency & Percentage $\%$ & & Frequency & Percentage \% \\
\hline \multirow[t]{3}{*}{ Do you practice hand washing with water and soap? } & Yes & 191 & $95.5 \%$ & Yes & 192 & $96.0 \%$ \\
\hline & No & 9 & $4.5 \%$ & No & 8 & $4.0 \%$ \\
\hline & Total & 200 & $100.0 \%$ & Total & 200 & $100.0 \%$ \\
\hline \multirow{2}{*}{$\begin{array}{l}\text { Do the school provide the students with facilities for } \\
\text { hand washing? }\end{array}$} & Yes & 182 & $91.0 \%$ & Yes & 186 & $93.0 \%$ \\
\hline & No & 18 & $9.0 \%$ & No & 14 & $7.0 \%$ \\
\hline
\end{tabular}


Table 4. Cont.

\begin{tabular}{|c|c|c|c|c|c|c|}
\hline & Total & 200 & $100.0 \%$ & Total & 200 & $100.0 \%$ \\
\hline \multirow{3}{*}{ Did you stop attending burial ceremonies? } & Yes & 71 & $35.5 \%$ & Yes & 79 & $39.5 \%$ \\
\hline & No & 129 & $64.5 \%$ & No & 121 & $60.5 \%$ \\
\hline & Total & 200 & $100.0 \%$ & Total & 200 & $100.0 \%$ \\
\hline \multirow{3}{*}{ Do you use hand sanitizer? } & Yes & 163 & $81.5 \%$ & Yes & 161 & $80.5 \%$ \\
\hline & No & 37 & $18.5 \%$ & No & 39 & $19.5 \%$ \\
\hline & Total & 200 & $100.0 \%$ & Total & 200 & $100.0 \%$ \\
\hline \multirow{3}{*}{ Do you bath with salt water } & Yes & 45 & $22.5 \%$ & Yes & 58 & $29.0 \%$ \\
\hline & No & 155 & $77.5 \%$ & No & 142 & $71.0 \%$ \\
\hline & Total & 200 & $100.0 \%$ & Total & 200 & $100.0 \%$ \\
\hline \multirow[t]{3}{*}{ Do you drink salt water? } & Yes & 29 & $14.5 \%$ & Yes & 56 & $28.0 \%$ \\
\hline & No & 171 & $85.5 \%$ & No & 144 & $72.0 \%$ \\
\hline & Total & 200 & $100.0 \%$ & Total & 200 & $100.0 \%$ \\
\hline \multirow[t]{3}{*}{ Do you use nose mask to prevent Ebola? } & Yes & 64 & $32.0 \%$ & Yes & 91 & $45.5 \%$ \\
\hline & No & 136 & $68.0 \%$ & No & 109 & $54.5 \%$ \\
\hline & Total & 200 & $100.0 \%$ & Total & 200 & $100.0 \%$ \\
\hline \multirow[t]{3}{*}{ Do you wear hand gloves to prevent Ebola? } & Yes & 101 & $50.5 \%$ & Yes & 136 & 68.0 \\
\hline & No & 99 & $49.5 \%$ & No & 64 & $32.0 \%$ \\
\hline & Total & 200 & $100.0 \%$ & Total & 200 & $100.0 \%$ \\
\hline
\end{tabular}

\section{REFERENCES}

Pringle CR, Fauquet CM, Mayor MA (2005). Virus Taxonomy-Eighth Report of the International committee on Taxonomy of viruses. San Diego United States of America. Elsevier/Academic Press, PP 609-614.

Grard G, Fair JN, Lee D (2012). A novel rhabdovirus associated with acute haemorrhagic fever in central Africa. PLOS Pathog. 8(9): e1002924.

Cohen J (2004). “Containing the threat - Don't Forget Ebola" PLOS Medicine. 1(3):59.

World Health Organisation (WHO) (2015). Fact sheets. http://www.who.int/mediacentre/factsheets/fs103/en/ Accessed 15 th August 2015.

Kuhn JH, Beckers S, Ebihara H (2010). Proposal for a revised taxonomy of the family Filoviridae: classification, names of taxa and viruses, and virus abbreviations. Archives of virology. 155(12): 2083-103.

Centres for Disease Control and Prevention (CDC) (2015). Outbreak of Ebola in Guinea, Liberia and Sierra Leone. www.cdc.gov. Accessed on $28^{\text {th }}$ August 2015.

Centres for Disease Control and Prevention (CDC) (2015). Guidelines for Evaluation of US Patients suspected of having Ebola virus Disease. www.emergency.cdc.gov. Accessed on $30^{\text {th }}$ August 2015.

World Health Organisation (WHO) (2015). Ebola virus disease factsheet No.103. www.who.int/mediacentre/factsheets/fs103/en/ Accessed on $15^{\text {th }}$ September 2015.
Centres for Disease Control and Prevention (CDC) (2015). Ebola Haemorrhagic fever signs and symptoms. www.cdc.gov/vhf/ebola/symptoms/index.html Accessed on 27th September 2015.

Goeijenbier M, Van-kampen JJ, Reusken CB (2014). Ebola virus disease: A review on epidemiology, symptoms, treatment and pathogenesis. Neth. J. Med. 72(9):442-8.

Catholic Relief Services (CRS) (2015). Study on Public Knowledge, Attitudes and Practices Relating to Ebola Virus Disease (EVD). reliefweb.int/report/sierraleone/study-public-knowledge-attitudes-and-practices. Accessed on $1^{\text {st }}$ October 2015.

Wikipedia (2015). Nnewi facts and figures. en.m.wikipedia.org/wiki/Nnewi. Accessed on 23 ${ }^{\text {rd }}$ August 2015.

National Population Commission of Nigeria (NPCN) (2009). 2006 National Population Census Report. www.population.gov.ng/index.php/censuses. Accessed 2nd October 2015.

Araoye MO (2004). Research Methodology with statistics for health and social science, first edition. Ilorin; Nathadex publishers,115-129.

Chan M (2014). Ebola virus disease in West Africa-no early end to the outbreak. N Engl, J Med. 391:1183-1185.

World Health Organisation (WHO) (2015). Sierra Leone: a tradition and a http://www.who.int/mediacentre/factsheets/Ebola. Accessed 5th October 2015). 